\title{
PERSEPSI MASYARAKAT TERHADAP KEBERADAAN HUTAN MANGROVE DI DESA SUNGAI KUPAH KECAMATAN SUNGAI KAKAP KABUPATEN KUBU RAYA
}

(The people perception toward the existence of mangrove forest in Sungai Kupah Village, Sungai Kakap Subdistrict, Kubu Raya District)

\author{
Rahayu Setya Ningsih, Emi Roslinda, Dwi Astiani \\ Fakultas Kehutanan Universitas Tanjungpura. Jalan Imam Bonjol Pontianak 78124 \\ Email : rahayusetyaningsihh@gmail.com
}

\begin{abstract}
People's perception on mangrove forest is one form of mangrove responses concerning the function and benefits of mangrove ecosystems including physical, biological, chemical, economic and social benefits. One of example mangrove forests is Sungai Kupah village, Sungai Kakap subdistrict, Kubu Raya district. This study aims to understand people's perceptions of the mangrove forests in the Sungai Kupah village and to understand the relationship between perceptions of the individual factors of age, education, knowledge, cosmopolitan levels, income levels, and dependability. The research uses the survey method and analyzed with Kendall tau's correlation and descriptive analysis. People's perception on mangrove forests in the Sungai Kupah village it's positively inclined, which is $51,14 \%$. Knowledge factor have a significant positive correlation; Education, income, cosmopolitan and dependency factors are low in their positive correlations; While age and distance factors tend have a negative insignificant correlation with people's perception of mangrove forests in the village of the Sungai Kupah. The perception can be used as a reference to bringing communities into further mangrove.
\end{abstract}

Keywords : Communities, individual factors, mangrove forests, perception, qualitative data

\section{PENDAHULUAN}

Hutan mangrove merupakan salah satu formasi hutan yang habitatnya berada di perbatasan daratan dan lautan. Mangrove memiliki keunikan tersendiri dibandingkan dengan yang lain, keunikannya terletak pada formasinya yang tersusun rapi dari daratan hingga pinggir pantai. Keunikan lainnya terletak pada keanekaragaman flora dan fauna serta habitat tempat hidup mangrove itu sendiri (Kustanti dkk, 2014).

Persepsi adalah suatu proses penilaian seseorang/sekelompok orang terhadap objek, peristiwa, atau stimulus dengan melibatkan pengalamanpengalaman yang berkaitan dengan objek tersebut (Ni'am dan Mussadun, 2014). Persepsi masyarakat terhadap keberadaan hutan mangrove dapat diartikan sebagai penilaian masyarakat terhadap hutan mangrove berdasarkan fungsi dan manfaat baik fisik, biologis, ekonomis, maupun sosial.

Sungai Kupah merupakan salah satu desa yang berada di Kecamatan Sungai Kakap, Kabupaten Kubu Raya, Provinsi Kalimantan Barat, termasuk salah satu desa yang berada di wilayah pesisir di Kecamatan Sungai Kakap yang berbatasan langsung dengan Kabupaten Mempawah yang berjarak sekitar $20 \mathrm{KM}$ dari pinggiran Kota pontianak. Desa yang disebelah baratnya berbatasan 
langsung dengan laut Natuna ini memiliki hutan mangrove yang dalam 2 tahun terakhir ini sedang dikembangkan menjadi objek wisata. Bagaimana kondisi mangrove di suatu tempat memiliki hubungan dengan bagaimana persepsi masyarakat di tempat tersebut. Persepsi yang benar terhadap suatu objek sangat diperlukan, sebab persepsi merupakan dasar pembentukan sikap dan perilaku. Asmara dan Suhirman (2012) menyatakan bahwa perilaku adalah hasil persepsi dan persepsi yang salah bisa menimbulkan perilaku yang salah.

Berdasarkan permasalahan yang telah dikemukakan, maka dibuat rumusan (1) Bagaimana persepsi masyarakat terhadap keberadaan hutan mangrove di Desa Sungai Kupah, Kecamatan Sungai Kakap Kabupaten Kubu Raya?, (2) Apakah faktor-faktor individu tingkat umur, tingkat pendidikan, tingkat pengetahuan, tingkat pendapatan, tingkat kosmopolitan dan tingkat ketergantungan masyarakat terhadap hutan mangrove berpengaruh terhadap persepsi masyarakat mengenai keberadaan hutan mangrove di Desa Sungai Kupah, Kecamatan Sungai Kakap Kabupaten Kubu Raya? Adapun tujuan dari penelitian (1) Untuk mengkaji persepsi masyarakat Desa Sungai Kupah terhadap keberadaan hutan mangrove di Desa Sungai Kupah, (2) Untuk menganalisis faktor-faktor individu tingkat umur, pendidikan, pengetahuan, pendapatan, tingkat kosmopolitan, tingkat ketergantungan masyarakat terhadap hutan mangrove dalam mempengaruhi persepsi masyarakat mengenai keberadaan hutan mangrove di Desa Sungai Kupah.

\section{METODE PENELITIAN}

Penelitian ini dilaksanakan di Desa Sungai Kupah Kecamatan Sungai Kakap Kabupaten Kubu Raya Kalimantan Barat dengan lama waktu pengambilan data dilapangan kurang lebih 1 bulan. Penelitian dilakukan terhadap 4 dusun yaitu Dusun Sepakat, Dusun Adil, Dusun Makmur, dan Dusun Sejahtera.

Teknik pengambilan data dilakukan dengan teknik wawancara langsung dibantu dengan alat berupa kuisoner yang berisikan rangkaian pertanyaan mengenai sesuatu hal yang terkait persepsi masyarakat terhadap keberadaan hutan mangrove di Desa Sungai Kupah Kecamatan Sungai Kakap. Objek penelitian adalah persepsi masyarakat terhadap keberadaan hutan mangrove di Desa Sungai Kupah Kecamatan Sungai Kakap Kabupaten Kubu Raya dan responden dalam penelitian ini adalah masyarakat Desa Sungai Kupah.

Metode survey digunakan dalam penelitian ini dan untuk teknik pengambilan sampel yaitu menggunakan Purposive Random Sampling. Dalam menentukan besarnya ukuran sampel yang digunakan dalam penelitian ini akan digunakan dengan rumus Slovin (Kusmayadi dan Endar,2000) :

$n i=\frac{N_{i}}{1+\sum N_{i} \cdot e^{2}}$

Keterangan:

$n_{\mathrm{i}}$ : Jumlah sampel responden dusun ke-i

$\mathrm{N}_{\mathrm{i}}$ : Jumlah populasi responden dusun ke-i 
e : batas toleransi kesalahan (dalam penelitian ini adalah $10 \%$ atau 0,1 )

Kriteria masyarakat yang akan dijadikan responden secara purposive random sampling adalah sebagai berikut : (1) Masyarakat Desa Sungai Kupah, (2) Sebagai kepala keluarga, (3) Berdomisili atau menetap minimal 5 tahun. Berdasarkan perhitungan menggunakan rumus Slovin tersebut didapat total 88 responden. Total 88 responden tersebut diluar sampel untuk uji validitas dan reliabilitas sebanyak 15 responden dari 802 KK.

Data penelitian yang dikumpulkan terdiri dari 2 (dua) bentuk data yakni data bersifat kuantitatif dan data yang bersifat kualitatif. Untuk data bentuk kuantatif ditabulasi sebagaimana adanya, sedangkan data bentuk kualitatif dirubah kebentuk data kuantitatif menggunakan skala Likert. Skor-skor yang diperoleh kemudian dijumlahkan secara keseluruhan dan akan diambil nilai ratarata untuk setiap variabel yang terdapat pada kuisioner. Berdasarkan total skor dari nilai bobot masing-masing item pertanyaan, selanjutnya dari lima kategori tersebut dirubah menjadi tiga kategori (Tinggi, sedang, rendah). Untuk merubah penilaian jawaban responden dari 5 (lima) kategori menjadi 3 (tiga) kategori digunakan rumus persamaan Confidence Interval (selang kepercayaan) menurut Hasril Hitam (1980) sebagai berikut :

$C I=\bar{x} \pm t . S x$

Keterangan :

CI: Confidence Interval (selang kepercayaan)

$\bar{x}$ : Nilai rata-rata jawaban responden.

$\mathrm{t}$ : $\mathrm{t}$ tabel kepercayaan $(0,88)$.
Sx: Standar Error, dengan rumus berikut :

$\mathrm{Sx}=\sqrt{1-I S\left\{\frac{S d^{2}}{n}\right\}}$

Dimana :

Sx: Standar Error

IS: Intensitas Sampling

$\mathrm{Sd}^{2}$ : varians

n: Jumlah Sampel

Berdasarkan persamaan di atas maka dikategorikan sebagai berikut :

- Tinggi, Jika nilai selang kepercayaan sebesar $\geq \bar{x}+t_{\text {tabel. }} . S x$

- Sedang, Jika nilai selang kepercayaan berada antara sebesar $\bar{x}-\mathrm{t}_{\text {tabel.Sx }}$ sampai $<\bar{x}+\mathrm{t}_{\text {tabel. }}$ Sx

- Rendah, jika nilai selang kepercayaan sebesar $<\bar{x}-\mathrm{t}_{\text {tabel. }}$.Sx

Selanjutnya data tersebut dianalisis dengan uji Korelasi Kendall Tau dengan rumus menurut Sugiyono (2001) sebagai berikut :

$\tau=\frac{\sum A-\sum B}{\frac{N(N-1)}{2}}$

Dimana :

$\tau=$ koefesien korelasi kendall tau yang besarnya $(-1<0<1)$

$\mathrm{A}=$ jumlah rangkaian atas

$\mathrm{B}=$ jumlah rangkaian bawa

$\mathrm{N}=$ jumlah gagasan sampel

Untuk menentukan apakah hipotesis di terima atau tidak, digunakan tingkat signifikan $0,05 \quad(\quad \mathrm{Z}=\%)$ dengan ketentuan sebagai berikut :

- Jika $Z_{\text {hitung }} \leq \mathrm{Z}_{\text {tabel }}$ atau Asymp Sig $<0,05$ maka tolak $\mathrm{H}_{0}$ terima $\mathrm{H}_{1}$

- Jika $\mathrm{Z}_{\text {hitung }} \geq \mathrm{Z}_{\text {tabel }}$ atau Asymp Sig $\geq 0,05$ maka terima $\mathrm{H}_{0}$ tolak $\mathrm{H}_{1}$

- Nilai koefesien positif (+) menunjukkan adanya hubungan positif antara variabel bebas dengan variabel terikat 
- Nilai koefesien negatif (-) menunjukkan adanya hubungan negatif antara variabel bebas dengan variabel terikat.

\section{HASIL DAN PEMBAHASAN}

Karakteristik Responden Berdasarkan Tingkat Umur

Karakteristik responden menurut tingkat umur dalam penelitian ini dikelompokan dalam 3 (tiga) kategori yaitu responden yang berumur $<41$ tahun, 41-44 tahun, dan $\geq 45$ tahun, penentuan pengkategorian ini menggunakan rumus persamaan Confidence Interval (selang kepercayaan). Berdasarkan hasil pengamatan dari 88 responden penelitian diperoleh frekuensi kategori responden menurut kelompok umur yang disajikan pada Tabel 1.

Tabel 1. Karakteristik Responden Berdasarkan Tingkat Umur (Respondents Characteristic Based On Age)

\begin{tabular}{|c|c|c|}
\hline Kategori Umur (Tahun) & Frekuensi & Persentase $(\%)$ \\
\hline$<41$ & 45 & 51,14 \\
\hline $41-44$ & 7 & 7,95 \\
\hline$\geq 45$ & 36 & 40,91 \\
\hline Jumlah & 88 & $100 \%$ \\
\hline
\end{tabular}

Sumber : Hasil Analisis Data Primer, 2019

Berdasarkan hasil penelitian yang dilakukan bahwa yang terbanyak adalah kategori usia <41 tahun yaitu sebanyak $51,14 \%$. Hal ini dikarenakan masyarakat dengan umur tersebut lebih mudah untuk diwawancarai secara langsung. Kemudian hasil terbanyak berikutnya adalah kategori usia $\geq 45$ tahun sebanyak $40,91 \%$ dan responden dengan kategori usia 41-44 tahun sebanyak 7,95\%.
Karakteristik Responden Berdasarkan Tingkat Pendidikan

Identitas responden menurut tingkat pendidikan dalam penelitian ini dikelompokan dalam 3 (tiga) kategori yakni dasar (tidak sekolah dan SD), menengah (SMP) dan tinggi (SMA dan Kuliah), frekuensi kategori respoden menurut tingkat pendidikan yang disajikan pada Tabel 2.

Tabel 2. Karakteristik Responden Berdasarkan Tingkat Pendidikan (Respondents Characteristic Based On Educational Level)

\begin{tabular}{|c|c|c|}
\hline Kategori Pendidikan & Frekuensi & Persentase $(\%)$ \\
\hline Dasar (tidak sekolah dan SD) & 56 & $63,64 \%$ \\
\hline Menengah (SMP) & 16 & $18,18 \%$ \\
\hline Tinggi (SMA dan Kuliah) & 16 & $18,18 \%$ \\
\hline Jumlah & 88 & $100 \%$ \\
\hline
\end{tabular}

Sumber : Hasil Analisis Data Primer, 2019 
Dari hasil penelitian menunjukkan bahwa tingkat pendidikan terbanyak responden terdapat pada tingkat pendidikan dasar sebanyak $63,64 \%$. Hal ini dikarenakan banyak masyarakat yang memiliki tingkat pendidikan dasar hanya dapat bekerja sebagai petani dan nelayan di dalam Desa Sungai Kupah, susahnya mencari pekerjaan serta banyak perusahaan yang mengharuskan pegawainya memiliki tingkat pendidikan tinggi menjadi salah satu alasan masyarakat yang hanya memiliki tingkat pendidikan dasar memilih untuk bekerja di dalam desa saja. Tingkat pendidikan menengah dan tinggi memiliki nilai frekuensi yang sama yaitu masingmasing 16 responden.

Karakteristik Responden Berdasarkan Tingkat Pengetahuan

Karakteristik responden menurut tingkat pengetahuan dalam penelitian ini dikelompokan dalam 3 (tiga) kategori yakni rendah, sedang dan tinggi, frekuensi kategori respoden menurut tingkat pengetahuan yang disajikan pada Tabel 3.

Tabel 3. Karakteristik Responden Berdasarkan Tingkat Pengetahuan (Respondents Characteristic Based On Knowledge)

\begin{tabular}{|c|c|c|}
\hline Tingkat Pengetahuan & Frekuensi & Persentase $(\%)$ \\
\hline Rendah & 30 & 34,09 \\
\hline Sedang & 9 & 10,23 \\
\hline Tinggi & 49 & 55,68 \\
\hline Jumlah & 88 & $100 \%$ \\
\hline
\end{tabular}

Sumber : Hasil Analisis Data Primer, 2019

Berdasarkan hasil penelitian pada tingkat pengetahuan yang terbanyak adalah responden dengan kategori tingkat pengetahuan tinggi sebanyak 55,68\%. Hal ini dikarenakan sudah banyak banyak masyarakat di Desa Sungai Kupah yang sudah mengetahui tentang fungsi dan manfaat dari keberadaan hutan mangrove.
Karakteristik responden berdasarkan tingkat pendapatan

Karakteristik responden menurut tingkat pendapatan dalam penelitian ini dikelompokan dalam 3 (tiga) kategori yakni rendah, sedang dan tinggi, dimana berdasarkan hasil pengamatan dari 88 responden penelitian diperoleh frekuensi kategori respoden menurut tingkat pendapatan yang disajikan pada Tabel 4

Tabel 4. Karakteristik Responden Berdasarkan Tingkat Pendapatan (Respondents Characteristic Based On Income levels)

\begin{tabular}{|c|c|c|}
\hline Tingkat Pendapatan $(\mathrm{Rp})$ & Frekuensi & Persentase $(\%)$ \\
\hline$<1.369 .287$ & 34 & 38,64 \\
\hline $1.369 .287-1.582 .985$ & 25 & 28,41 \\
\hline$\geq 1.582 .985$ & 29 & 32,95 \\
\hline Jumlah & 88 & $100 \%$ \\
\hline
\end{tabular}

Sumber : Hasil Analisis Data Primer, 2019 
Berdasarkan hasik penelitian pada tingkat pendapatan diperoleh persentase frekuensi kelompok tingkat pendapatan masyarakat Desa Sungai Kupah yang bervariasi dimana persentase frekuensi terbanyak adlah tingkat pendapatan rendah sebanyak 38,64\%. Hal ini dikarenakan pekerjaan masyarakat sebagian besar hanya berprofesi sebagai petani dan nelayan serta sebagian bekerja sebagai pegawai swasta. Penghasilan sebagai seorang petani dan nelayan tidaklah dapat dipastikan, hal ini dikarenakan tak setiap hari bisa mendapatkan penghasilan, serta besar kecilnya penghasilan juga tergantung dari hasil panen dan perolehan yang didapat. Rendahnya tingkat pendapatan masyarakat tentulah dipengaruhi oleh susahnya mencari pekerjaan di zaman sekarang ini. Dapat dilihat dalam tabel 2 mengenai karakteristik responden berdasarkan tingkat pendidikan dimana pendidikan terakhir terbanyak adalah pendidikan tingkat dasar, hal ini tentu menjadi salah satu faktor yang menyebabkan masyarakat sulit untuk mencari pekerjaan, dimana untuk saat ini tingkat pendidikan menjadi salah satu syarat dalam melamar pekerjaan. Kemudian hasil responden terbanyak selanjutnya adalah kategori tinggi sebanyak 32,95 dan kategori sedang sebanyak 28,41.

Karakteristik responden berdasarkan tingkat kosmopolitan

Karakteristik responden menurut tingkat kosmopolitan dalam penelitian ini dikelompokan dalam 3 (tiga) kategori yakni rendah, sedang dan tinggi, dimana berdasarkan hasil pengamatan dari 88 responden penelitian diperoleh frekuensi kategori respoden menurut tingkat kosmopolitan yang disajikan pada Tabel 5.

Tabel 5. Karakteristik Responden Berdasarkan Tingkat Kosmopolitan (Respondents Characteristic Based On Cosmopolitan levels)

\begin{tabular}{|c|c|c|}
\hline Tingkat Kosmopolitan & Frekuensi & Persentase $(\%)$ \\
\hline Rendah & 31 & 35,23 \\
\hline Sedang & 29 & 32,95 \\
\hline Tinggi & 28 & 31,82 \\
\hline Jumlah & 88 & $100 \%$ \\
\hline
\end{tabular}

Sumber : Hasil Analisis Data Primer, 2019 
Berdasarkan Tabel 6. diperoleh persentase frekuensi kelompok tingkat kosmopolitan masyarakat Desa Sungai Kupah yang bervariasi dimana persentase frekuensi tingkat kosmopolitan rendah lebih besar dibanding tingkat kosmopolitan tinggi dan sedang. Frekuensi tingkat kosmopolitan rendah sebesar 31 $(35,23 \%)$, tingkat kosmopolitan sedang $29(32,95 \%)$ dan frekuensi tingkat kosmopolitan tinggi sebesar 27 $(31,82 \%)$.

Berdasarkan Tabel 6. diperoleh persentase frekuensi kelompok tingkat kosmopolitan masyarakat Desa Sungai Kupah yang bervariasi dimana persentase frekuensi tingkat kosmopolitan rendah lebih besar dibanding tingkat kosmopolitan tinggi dan sedang. Frekuensi tingkat kosmopolitan rendah sebesar 31 $(35,23 \%)$, tingkat kosmopolitan sedang $29(32,95 \%)$ dan frekuensi tingkat kosmopolitan tinggi sebesar 27 $(31,82 \%)$.

Karakteristik responden berdasarkan tingkat ketergantungan terhadap hutan mangrove

Identitas responden menurut tingkat ketergantungan dalam penelitian ini dikelompokan dalam 3 (tiga) kategori yakni rendah, sedang dan tinggi, frekuensi kategori respoden menurut tingkat kosmopolitan yang disajikan pada Tabel 6.

Tabel 6. Karakteristik Responden Berdasarkan Tingkat Ketergantungan Terhadap Hutan Mangrove (The Respondents Characteristics Are Based On High Dependence On Mangrove Forests)

\begin{tabular}{|c|c|c|}
\hline Tingkat Ketergantungan & Frekuensi & Persentase $(\%)$ \\
\hline Rendah & 36 & 40,91 \\
\hline Sedang & 9 & 10,23 \\
\hline Tinggi & 43 & 48,86 \\
\hline Jumlah & 88 & $100 \%$ \\
\hline
\end{tabular}

Sumber : Hasil Analisis Data Primer, 2019

Berdasarkan hasil penelitian bahwa tingkat ketergantungan responden terhadap hutan mangrove adalah tinggi sebanyak 48,86\%. Sebagian Masyarakat Desa Sungai Kupah masih memanfaatkan hasil dari hutan mangrove seperti memanfaatkan daun nipah sebagai atap rumah dan memanfaatkan buah-buahan yang di hasilkan sebagai makanan. Sedangkan untuk pemanfaatan yang dapat merusak keberadaan hutan mangrove seperti menebang pohon untuk dijadikan kayu bakar dan bahan bangunan sudah tidak di lakukan lagi.

Persepsi Masyarakat Desa Sungai Kupah Terhadap Keberadaan Hutan Mangrove

Tingkat persepsi responden dalam penelitian ini dikelompokkan dalam 3 (tiga) kategori yaitu positif, netral dan negatif dimana frekuensi kategori yang disajikan pada Tabel 7. 
Tabel 7. Persepsi Masyarakat Desa Sungai Kupah (Perseptions Of The Kupah River Village)

\begin{tabular}{|c|c|c|}
\hline Tingkat Persepsi & Frekuensi & Persentase $(\%)$ \\
\hline Positif & 45 & 51,14 \\
\hline Netral & 9 & 10,23 \\
\hline Negatif & 34 & 38,64 \\
\hline Jumlah & 88 & $100 \%$ \\
\hline
\end{tabular}

Sumber : Hasil Analisis Data Primer, 2019.

Berdasarkan hasil penelitian pada tingkat persepsi yang terbanyak adalah pesepsi positif sebanyak 51,14\% terhadap keberadaan hutan mangrove. Tingginya tingkat persepsi positif masyarakat dikarenakan banyak masyarakat di Desa Sungai Kupah sudah mulai menyadari akan manfaat dan pentingnya keberadaan hutan mangrove tersebut.
Hubungan Variabel Terikat Dan Variabel Bebas.

Pendugaan hubungan variabel terikat dan variabel bebas dilakukan dengan uji korelasi kendall tau yang terdiri dari 1 (satu) variabel terikat dan 7 (tujuh) variabel bebas. Hasil uji korelasi Kendall Tau variabel terikat dengan variabel bebas seperti tertera pada Tabel 8.

Tabel 8. Hasil Uji Korelasi Kendall Tau (Kendall Correlation Test Results)

\begin{tabular}{llccc}
\hline No & $\begin{array}{c}\text { Variabel } \\
\text { Terikat } \\
\text { Persepsi }\end{array}$ & \multicolumn{2}{c}{ Variabel Bebas } & Keterangan \\
\hline & & & Siq & \\
& & Correlation & $(2-$ tailed $)$ & \\
1. & Umur & $-0,023$ & 0,761 & Berhubungan Negatif Tidak Signifikan \\
2. & Pengetahuan & 0,403 & 0,000 & Berhubungan Positif Signifikan \\
3. & Pendidikan & 0,106 & 0,222 & Berhubungan Positif Tidak Signifikan \\
4. & Pendapatan & 0,085 & 0,296 & Berhubungan Positif Tidak Signifikan \\
5. & Kosmopolitan & 0,189 & 0,015 & Berhubungan Positif Signifikan \\
6. & ketergantungan & 0,040 & 0,601 & Berhubungan Positif Tidak Signifikan \\
\hline Sun
\end{tabular}

Sumber : Hasil Olah Data Primer 2019

Hubungan Umur Terhadap Persepsi Masyarakat Tentang Keberadaan Hutan Mangrove di Desa Sungai Kupah

Dari hasil Uji Korelasi Kendall Tau diketahui nilai Sig.(2-tailed) sebesar 0,761 dan nilai correlation coefficient sebesar $-0,023$. Hasil tersebut memiliki signifikansi lebih besar dari 0,05 yaitu $0,761>0,05$, dan nilai correlation coefficient yang negatif. Sehingga dapat dikatakan bahwa terdapat korelasi negatif yang tidak signifikan antara variabel umur dengan variabel persepsi masyarakat terhadap keberadaan hutan mangrove. Dengan nilai correlation coefficient sebesar -0,023 maka tingkat keeratan hubungan antara variabel umur dengan variabel persepsi dapat dikatakan sangat lemah. Oleh karena itu hipotesis yang menduga bahwa terdapat hubungan antara tingkat umur terhadap persepsi masyarakat Desa Sungai Kupah terhadap 
keberadaan hutan mangrove di Desa Sungai Kupah Kecamatan Sungai Kakap Kabupaten Kubu Raya ditolak. Hal ini dikarenakan tidak adanya hubungan antara tingkat umur terhadap persepsi masyarakat tentang keberadaan hutan mangrove artinya persepsi masyarakat terhadap keberadaan hutan mangrove di Desa Sungai Kupah tidak di pengaruhi oleh umur. Hal ini dikarenakan persepsi mengenai keberadaan hutan mangrove yang disampaikan oleh masyarakat tidak terlalu dipengaruhi oleh tingkat umur masyarakat, positif atau negatifnya persepsi masyarakat sebenarnya di pengaruhi oleh kesadaran masyarakat itu sendiri, dimana tingkat kesadaran ini tidak memandang umur sebagai patokan. Menurut Kadhapi (2015) usia tidak membatasi seseorang untuk mengetahui dan menerima manfaat dari segala sesuatu bagi kehidupan setiap individu. Susanto (2010) menyatakan bahwa umur masyarakat bertambah akan tetapi tidak mempengaruhi secara nyata persepsi masyarakat. Hal ini terjadi karena umur tua belum tentu lebih persepsinya dibandingkan dengan umur yang lebih muda. Karena kemampuan dan pengalaman usia tua tidak menggambarkan persepsi yang baik dari pada yang muda.

Hubungan Pengetahuan Terhadap Persepsi Masyarakat Tentang Keberadaan Hutan Mangrove di Desa Sungai Kupah

Berdasarkan hasil Uji Korelasi Kendall Tau diketahui nilai Sig.(2tailed) sebesar 0,000 dan nilai correlation coefficient sebesar 0,403.
Hasil nilai Sig.(2-tailed) tersebut memiliki signifikansi kurang dari 0,05 yaitu $0,000<0,05$ dan hasil correlation coefficient bernilai positif sehingga dapat disimpulkan bahwa terdapat korelasi positif yang signifikan antara variabel persepsi dengan variabel pengetahuan. Nilai correlation coefficient sebesar 0,403 maka tingkat keeratan hubungan antara variabel pengetahuan dengan variabel persepsi dapat dikatakan sedang. Oleh karena itu hipotesis yang menduga bahwa terdapat hubungan antara tingkat pengetahuan mengenai hutan mangrove terhadap persepsi masyarakat Desa Sungai Kupah terhadap keberadaan hutan mangrove di Desa Sungai Kupah Kecamatan Sungai Kakap Kabupaten Kubu Raya diterima. Persepsi masyarakat signifikan terhadap pengetahuan tentang keberadaan hutan mangrove dikarenakan pengetahuan masyarakat berhubungan dengan persepsi masyarakat, tinggi rendahnya tingkat pengetahuan masyarakat berpengaruh terhadap persepsi masyarakat tersebut. Masyarakat yang mempunyai pengetahuan tinggi cenderung mengetahui fungsi dan manfaat keberadaan hutan mangrove. Masyarakat yang mempunyai pengetahuan tinggi mengenai manfaat keberadaan hutan mangrove adalah masyarakat yang mempunyai pemahaman cukup luas mengenai keberadaan hutan mangrove, sehingga antara pengetahuan dan persepsi masyarakat mengenai keberadaan hutan mangrove mempunyai korelasi yang positif dan signifikan. Hal sejalan 
dengan hasil penelitian yang di lakukan oleh Khairiansyah (2018) mengenai persepsi masyarakat terhadap keberadaan hutan mangrove di Kelurahan Kuala Kecamatan Singkawang Barat Kota Singkawang yang menyatakan bahwa terdapat hubungan yang signifikan antara tingkat pengetahuan dengan persepsi masyarakat terhadap keberadaan hutan mangrove di Kelurahan Kuala. Satria (tahun) dalam penelitiannya juga menyatakan bahwa faktor pengetahuan mempengaruhi persepsi masyarakat terhadap usaha tani tanaman karet di Desa Nanga Tekungai Kecamatan Serawai Kabupaten Sintang Provinsi Kalimantan Barat.

Hubungan Pendidikan Terhadap Persepsi Masyarakat Tentang Keberadaan Hutan Mangrove di Desa Sungai Kupah

Dari hasil Uji Korelasi Kendall Tau diketahui nilai Sig.(2-tailed) sebesar 0,222 dan nilai correlation coefficient sebesar 0,106. Nilai tersebut memiliki signifikansi lebih dari 0,05 yaitu 0,222 > 0,05, dan nilai correlation coefficient yang positif, sehingga dapat dikatakan bahwa terdapat korelasi positif yang tidak signifikan antara variabel pendidikan dengan variabel persepsi masyarakat terhadap keberadaan hutan mangrove. Nilai correlation coefficient sebesar 0,106 maka tingkat keeratan hubungan antara variable pendidikan dengan variabel persepsi dapat dikatakan sangat lemah. Oleh karena itu hipotesis yang menduga bahwa terdapat hubungan antara tingkat pendidikan terhadap persepsi masyarakat Desa Sungai Kupah terhadap keberadaan hutan mangrove di Desa Sungai Kupah Kecamatan Sungai Kakap Kabupaten Kubu Raya ditolak. Hal ini dikarenakan persepsi mengenai keberadaan hutan mangrove yang disampaikan oleh masyarakat tidak terlalu dipengaruhi oleh tingkat pendidikan baik tingkat SD, SMP ataupun SMA-perguruan tinggi. Hal ini dikarenakan persepsi yang di sampaikan oleh masyarakat merupakan hasil dari pengalaman mereka. Shaleh (2009) menyatakan bahwa pengalaman terdahulu sangat mempengaruhi bagaimana seseorang mempersepsikan dunianya.

Tingkat pendidikan yang ada pada masyarakat hanyalah sebagai formalitas bukan yang menjadi dasar pemikiran mengenai persepsi mereka terhadap keberadaan hutan mangrove. Oleh karena itu walaupun masyarakat yang sudah menempuh tingkat pendidikan SD, SMP, SMA bahkan Perguruan tinggi juga harus mendapatkan tambahan informasi terkait dengan manfaat dari keberadaan hutan mangrove.

Hubungan Pendapatan Terhadap Persepsi Masyarakat Tentang Keberadaan Hutan Mangrove di Desa Sungai Kupah

Dari hasil Uji Korelasi Kendall Tau diketahui nilai Sig.(2-tailed) sebesar 0,296 dan nilai correlation coefficient sebesar 0,085. Nilai tersebut memiliki signifikansi lebih dari 0,05 yaitu 0,296 > 0,05 , dan nilai correlation coefficient yang positif, sehingga dapat dikatakan bahwa terdapat korelasi positif yang 
tidak signifikan antara variabel pendapatan dengan variabel persepsi masyarakat terhadap keberadaan hutan mangrove. Nilai correlation coefficient sebesar 0,085 maka tingkat keeratan hubungan antara variable pendapatan dengan variabel persepsi dapat dikatakan sangat lemah. Oleh karena itu hipotesis yang menduga bahwa terdapat hubungan antara tingkat pendapatan masyarakat terhadap persepsi masyarakat Desa Sungai Kupah terhadap keberadaan hutan mangrove di Desa Sungai Kupah Kecamatan Sungai Kakap Kabupaten Kubu Raya ditolak.

Persepsi masyarakat tidak signifikan terhadap tingkat pendapatan masyarakat dikarenakan pekerjaan masyarakat tidak berhubungan dengan persepsi masyarakat terhadap keberadaan hutan mangrove hal ini dikarenakan masyarakat desa sungai kupah pada umumnya bekerja sebagai petani, nelayan dan pegawai swasta. Meskipun banyak masyarakat yang mengetahui bahwa hutan mangrove dapat di manfaatkan sebagai lahan pertanian, tetapi banyak dari masyarakat yang tidak memanfaatkan fungsi tersebut dikarenakan masyarakat telah mengetahui bahwa kawasan mangrove tersebut adalah kawan konservasi.

Hubungan Kosmopolitan Terhadap Persepsi Masyarakat Tentang Keberadaan Hutan Mangrove di Desa Sungai Kupah

Dari hasil Uji Korelasi Kendall Tau diketahui nilai Sig.(2-tailed) sebesar 0,015 dan nilai correlation coefficient sebesar 0,189. Nilai tersebut memiliki signifikansi lebih dari 0,05 yaitu 0,015> 0,05 dan nilai correlation coefficient yang positif, sehingga dapat dikatakan bahwa terdapat korelasi positif yang tidak signifikan antara variabel kosmopolitan dengan variabel persepsi masyarakat terhadap keberadaan hutan mangrove. Nilai correlation coefficient sebesar 0,189 maka tingkat keeratan hubungan antara variable kosmopolitan dengan variabel persepsi dapat dikatakan sangat lemah. Oleh karena itu hipotesis yang menduga bahwa terdapat hubungan antara tingkat kosmopolitan terhadap persepsi masyarakat Desa Sungai Kupah terhadap keberadaan hutan mangrove di Desa Sungai Kupah Kecamatan Sungai Kakap Kabupaten Kubu Raya ditolak. Hal ini dikarenakan persepsi mengenai keberadaan hutan mangrove yang disampaikan oleh masyarakat tidak terlalu dipengaruhi oleh tingkat kosmopolitan.

Kurangnya rasa keingintahuan masyarakat untuk mencari informasi mengenai hutan mangrove juga menjadi salah satu faktor penyebab kurangnya wawasan masyarakat akan manfaat dan pentingnya menjaga dan melestarikan keberadaan hutan mangrove. Di era yang semakin canggih sekarang ini masyarakat, teknologi yang ada hanya dimanfaatkan untuk hal-hal tertentu saja yang lebih menarik, contohnya banyak orang yang memanfaatkan televisi hanya untuk menonton sinetron saja, memanfaatkan internet hanya untuk bermain media sosial saja, dibandingkan untuk mencari informasi mengenai manfaat dan fungsi keberadaan hutan 
mangrove itu sangat sedikit atau hanya segelintir masyarakat yang menggunakannya.

Hubungan Tingkat Ketergantungan Masyarakat Dengan Hutan Mangrove Terhadap Persepsi Masyarakat Tentang Keberadaan Hutan Mangrove Di Desa Sungai Kupah

Dari hasil Uji Korelasi Kendall Tau diketahui nilai Sig.(2-tailed) sebesar 0,601 dan nilai correlation coefficient sebesar 0,040. Nilai tersebut memiliki signifikansi lebih dari 0,05 yaitu 0,601 > 0,05 , dan nilai correlation coefficient yang positif, sehingga dapat dikatakan bahwa terdapat korelasi positif yang tidak signifikan antara variabel tingkat ketergantungan dengan variabel persepsi masyarakat terhadap keberadaan hutan mangrove. Nilai correlation coefficient sebesar 0,040 maka tingkat keeratan hubungan antara variable ketergantungan dengan variabel persepsi dapat dikatakan sangat lemah. Oleh karena itu hipotesis yang menduga bahwa terdapat hubungan antara tingkat ketergantungan masyarakat terhadap hutan mangrove terhadap persepsi masyarakat Desa Sungai Kupah terhadap keberadaan hutan mangrove di Desa Sungai Kupah Kecamatan Sungai Kakap Kabupaten Kubu Raya ditolak. Hal ini dikarenakan persepsi mengenai keberadaan hutan mangrove yang disampaikan oleh masyarakat tidak terlalu dipengaruhi oleh tingkat ketergantungan masyarakat Desa Sungai Kupah terhadap hutan mangrove. Dalam penelitian Mayangsari (2017) menunjukkan bahwa persepsi masyarakat terhadap objek wisata mangrove di Desa Pasir Kecamatan Mempawah Hilir Kabupaten Mempawah dipengaruhi oleh tingkat ketergantungan masyarakat terhadap hutan mangrove dimana semakin tinggi tingkat ketergantungan maka semakin tinggi pula persepsi masyarakat. Rendahnya tingkat ketergantungan masyarakat Desa Sungai Kupah terhadap hutan mangrove dikarenakan kurangnya sumber daya yang dapat dimanfaatkan dari hutan mangrove tersebut serta jauhnya jarak yang harus ditempuh serta akses jalan yang masih kurang memadai menjadi salah satu faktor yang menyebabkan kurangnya masyarakat dalam memanfaatkan hutan mangrove tersebut.

Persepsi masyarakat tidaklah dipengaruhi oleh tingkat ketergantungan masyarakat terhadap hutan mangrove sendiri. Masyarakat desa sungai kupah saat ini sudah banyak yang tidak lagi memanfaatkan hasil dari hutan mangrove untuk memenuhi kebutuhan hidupnya dan hanya sebagian kecil dari masyarakat yang masih memanfaatkan hasil dari hutan mangrove. Hasil hutan mangrove yang banyak dimanfaatkan oleh masyarakat hanya sebatas buahbuahan serta daun nipah yang digunakan untuk pembuatan atap rumah. Pemanfaatan kayu dari hutan mangrove baik sebagai kayu bakar maupun bahan bangunan sudah tidak pernah dilakukan, adanya larangan dari pemerintah setempat serta tingkat kesadaran dan kepedulian masyarakat terhadap keberadaan hutan mangrove yang 
semakin tinggi menjadi alasan masyarakat mulai menjaga keberadaan serta kelestarian mangrove di Desa Sungai Kupah.

\section{Kesimpulan}

Berdasarkan hasil penelitian yang telah dilakukan di Desa Sungai Kupah Kecamatan Sungai Kakap Kabupaten Kubu Raya dapat disimpulkan hal-hal sebagai berikut:

1. Persepsi masyarakat Desa Sungai Kupah Terhadap Keberadaan Hutan Mangrove adalah positif.

2. Faktor individu tingkat pengetahuan dan tingkat kosmopolitan memiliki hubungan positif signifikan. Faktor individu tingkat pendidikan, tingkat pendapatan, tingkat ketergantungan masyarakat memiliki hubungan positif tidak signifikan, sedangkan faktor umur memiliki hubungan negatif tidak signifikan terhadap persepsi masyarakat Desa Sungai Kupah terhadap keberadaan hutan mangrove.

\section{Saran}

Persepsi masyarakat yang positif dapat menjadi modal bagi pengembangan mangrove di Desa Sungai Kupah, oleh karena itu masyarakat dapat diikutsertakan dalam membangun atau mengelola mangrove Desa Sungai Kupah.

\section{Ucapan Terima Kasih}

Saya mengucapkan terima kasih banyak kepada dosen pembimbing saya Ibu Dr. Emi Roslinda, S.Hut, M.Si. dan Ibu Prof. Ir. Dwi Astiani, M.Sc, M.Phil, Ph.D. yang telah dengan sabar membimbing saya selama ini, dan tidak lupa pula saya ucapkan terima kasih kepada ibu, adik dan alm bapak yang senantiasa selalu mendukung dan mendoakan saya, serta terimakasih kepada semua yang telah memberi bantuan dalam penelitian ini.

\section{Daftar Pustaka}

Asmara Y, Suhirman. 2012. Persepsi dan sikap Masyarakat Terhadap Kegiatan Ekowisata Kampung Cikidang. Jurnal Perencanaan Wilayah dan Kota A SAPPK. 1 (2) : 568 - 578 .

Hitam H. 1980. Dasar-Dasar Teori dan Penggunaan Teknik Pengambilan Contoh (Sampling Techniques) dalam Inventarisasi Hutan. Jakarta : Pradnya Paramita.

Khairiansyah M, Zainal S, Nugroho J. 2018. Persepsi masyarakat terhadap keberadaan hutan mangrove di Kelurahan Kuala Kecamatan Singkawang Barat Kota Singkawang. Jurnal Hutan Lestari 6 (2) : 416-427.

Kustanti A. 2013 Evolusi hak kepemilikan dan penataan para pihak pada pengelolaan ekosistem hutan mangrove dengan kemunculan tanah timbul. Disertasi. Pogram Pascasarjana Ilmu Pengelolaan Hutan. IPB. Bogor.

Kusmayadi, Endar S. 2000. Metodologi Penelitian Dalam Bidang Kepariwisataan. Jakarta : PT. Gramedia Pustaka Utama.

Mayangsari D, Muin S, Siahaan S. 2017. Persepsi masyarakat terhadap keberadaan objek ekowisata mangrove di Desa Pasir Kecamatan Mempawah Hilir Kabupaten Mempawah. Jurnal Hutan Lestari 5 (3) : 668-679. 
JURNAL HUTAN LESTARI (2020)

Vol. 8 (2) : 365 - 378

Shaleh AR. 2009. Psikologi Suatu Pengantar dalam Perspektif Islam. Jakarta : Kencana.

Sugiyono. 2001. Statistik Nonparametrik Untuk Penelitian. Bandung. Alfabeta.

Susanto, Anang. 2010. Persepsi Masyarakat Terhadap Cagar Alam Gunung Picis. Fakultas Pertanian Universitas Merdeka Madiun. Madiun 